\title{
FAILURE TO ARREST: A PILOT STUDY OF POLICE RESPONSE TO DOMESTIC VIOLENCE IN RURAL ILLINOIS
}

\author{
SARA R. BENSON*
}

I. Introduction

II. From Inaction to Mandatory Action: The History of Mandatory

Arrest Laws.

III. Law Governing Police Action in Illinois

A. The Illinois Domestic Violence Act

B. The Illinois Domestic Violence Protocol for Law

Enforcement

IV. Rural Domestic Violence Survivors' Narratives

V. Improving Rural Law Enforcement Response to Domestic

Violence Calls.

VI. Conclusion. 703

\section{INTRODUCTION}

Picture a rural community. 'In this particular community, there is no

\footnotetext{
- Visiting Assistant Professor, University of Illinois College of Law; L.L.M. 2005, Boalt Hall School of Law, University of California, Berkeley; J.D. 2001, University of Houston Law Center. The author would like to thank Martha Fineman and the Feminist Legal Theory Project for hosting her at Emory while she worked on research for this Article. She would also like to thank Lawrence Solum, David Meyer, Nina Tarr, Amitai Aviram and Christopher Buccafusco for reviewing an early draft of this Article, as well as the faculty of the University of Illinois College of Law for providing her with insightful feedback after a presentation of this Article as a work in progress. Finally, the author would like to thank Elizabeth L. Sweet, Ph.D., for her collaboration in constructing the research protocol, research design and coordinating the focus group meetings and Carol Fonseca, $\mathrm{PhD}$ candidate, for her valuable research assistance.

1. For purposes of this Article, a rural county is one that is defined as a nonmetropolitan county by the Office of Management and Budget ("OMB") with a population of less than 50,000. See OfFICE OF MGMT. \& BUdGet, OMB BULlETIN No. 08-01, UPDATE OF STATISTICAL AREA DeFINITIONS AND GUIDANCE ON THEIR USES (Nov. 20, 2007), http://www.whitehouse.gov/omb/bulletins/fy2008/b08-01.pdf. Note that micropolitan areas are counted as "non-rural" for purposes of this Article. See id. (defining Micropolitan Statistical Areas as areas that have an urban population between
} 
battered women's shelter. Additionally, there is no bus system in the area. As one survivor said, "It's a taxi cab, or you're walking." If you are unable to provide your own means of transportation to a domestic violence shelter outside of town, you may be unable to locate safe shelter quickly. In this community, you may not be able to obtain the help you seek to escape from an abusive relationship, especially if your abuser is wellknown. Community networks were described by one survivor as "a good ol' boy's club." In remote locations like these, the voices of domestic violence survivors are less frequently heard than their urban counterpartsespecially in legal academic discourse. ${ }^{4}$ Yet, this area of inquiry might be the most crucial focal point for legal domestic violence studies, as rural survivors face barriers to legal and economic access, assistance, and development that are compounded by the isolation of their physical location. $^{5}$

Thus, in the summer of 2007 , I conducted three focus groups in a rural domestic violence service center. ${ }^{6}$ To conduct these focus groups I

10,000 and 50,000 which is adjacent to a territory that has high social, economic, and community integration. Both counties within the service area of the domestic violence provider where the focus groups for this research took place are considered nonmetropolitan areas as defined by the OMB. See id. This Article does not adopt the census definition of rural, which defines rural as municipalities with populations of 2,500 or less. See U.S. CENSUS BuREAU, CENSUS 2000 URBAN AND RURAL CLASSIFICATION 12-1 (2006), http://www.census.gov/geo/www/GARM/Ch12GARM .pdf. However, most of the municipalities encompassed within the counties served by the domestic violence provider where the focus groups took place were considered rural under this definition as well, with about four exceptions. See U.S. CENSUS BUREAU, 2000 CENSUS POPUlation COMPARED TO 1990: IllinOIS MUNICIPALITIES, (2001), http://illinoisgis.ito.state.il.us/census2000/censusData/2000 /docs/munipop.pdf. The specific counties involved in the study will not be disclosed to protect the confidentiality of focus group participants and in accordance with University of Illinois Institutional Review Board protocol.

2. Interview with Focus Group 3, Domestic Violence Survivors (Sept. 19, 2007) (on file with the American University Journal of Gender, Social Policy \& the Law).

3. Interview with Focus Group 1, Domestic Violence Survivors (August 9, 2007) (on file with the American University Journal of Gender, Social Policy \& the Law).

4. Only a few secondary legal sources extensively discuss rural domestic violence in the United States. See, e.g., Lisa R. Pruitt, Place Matters: Domestic Violence and Rural Difference, 23 WIS. J.L. GENDER \& SOC'Y 347 (2008) (recognizing, as one of the few legal scholars conducting such research, the paucity of legal scholarship addressing rural domestic violence issues). See generally Joanna Lyn Grama, Women Forgotten: Difficulties Faced by Rural Victims of Domestic Violence, 14 AM. J. FAM. L. 173 (2000); Lisa R. Pruitt, Toward a Feminist Theory of the Rural, 2007 UTAH L. REV. 421 (2007); Wendy Boka, Note, Domestic Violence in Farming Communities: Overcoming the Unique Problems Posed by the Rural Setting, 9 DRAKE J. AGRIC. L. 389 (2004).

5. See Grama, supra note 4, at 180 (noting that a lack of access to and experience with the court system prevents many rural domestic violence victims from seeking court intervention).

6. Nine survivors of domestic abuse participated in the focus groups. Domestic violence advocates and staff members assisted with the recruitment of focus group participants. Methods for contacting potential participants included fliers at the service center and telephone contact on secure lines by service center staff. The fliers indicated that potential participants should contact a 1-800 number. The fliers also 
collaborated with Elizabeth L. Sweet. ${ }^{7}$ Although a study exists that documents how rural survivors perceive the law enforcement response to domestic violence, ${ }^{8}$ the study at hand is unique because the interviews were conducted in a focus group setting with domestic violence survivors. ${ }^{9}$ I asked the participants open-ended questions about their experiences with the legal system in the area of domestic violence services. ${ }^{10}$ In this way, participants could respond dynamically to each others' statements and agree or disagree with certain perceptions about the legal system. ${ }^{11} \mathrm{~A}$ theme quickly emerged from this discussion: the majority of participating women mentioned difficulty in their encounters with the police. Their narratives, which are incorporated in Section III below, illustrate problems

indicated that potential participants could discuss the study with service center staff if they did not have access to a telephone. Callers were asked to leave a message providing a secure telephone number and availability for a return telephone call. Members of the research team returned the phone call at the appropriate time, using safety measures to carefully ascertain whether it was appropriate to discuss the study at that time with the potential participant. Women were screened based on the following criteria: (1) they must have experienced domestic violence within the past seventeen years (since the establishment of the Illinois Family Violence Coordinating Councils in 1990); (2) they must have been between the ages of 18 and 64 years old (elderly women were excluded due to their status as a vulnerable population); (3) they must reside or have resided in a rural community in Illinois within the past seventeen years; and (4) they must have utilized community services in response to the violence, including shelter services, police response services, and court-related legal services.

7. Elizabeth Sweet's research pertained to economic development for survivors of violence.

8. See Neil Websdale \& Byron Johnson, The Policing of Domestic Violence in Rural and Urban Areas: The Voices of Battered Women in Kentucky, 6 PoLICING \& SOC'Y 297 (1997) (conducting 510 structured interviews with a random sample of battered women residing in spouse abuse shelters in Kentucky).

9. A similar study was conducted on a much larger scale in 2004; however, many of the focus group participants did not personally experience domestic violence and could not give responses based on personal knowledge. See T.K. Logan et al., Rural and Urban Women's Perceptions to Barriers to Health, Mental Health, and Criminal Justice Services: Implication for Victim Services, 19 VIOLENCE \& VICTIMS 37, 59 (2004) (conducting focus groups consisting of 128 women from both urban and rural areas). Additionally, a 2001 study focused on 'victims' opinions or perceptions of legal interventions," encouraging future researchers to use focus groups to explore women's preferences and perceptions related to domestic violence legal interventions. See Alisa Smith, Domestic Violence Laws: The Voices of Battered Women, 16 VIOLENCE \& VICTIMS 91, 109 (2001) (using surveys of ninety-three women in a Midwestern battered women's shelter to examine survivors' perceptions of legal interventions).

10. Focus groups were used as the source of gathering data for this investigation in order to study how rural norms, values, and practices affect domestic violence survivors' perceptions of the legal system. See NATASHA MACK ET AL, FAMILY Health InTERnational, Qualitative Research Methods: A Data Collector's FIELD GUIDE 52 (2005), http://www.fhi.org/en/rh/pubs/booksreports /qrm_datacoll.htm (select "download the PDF") (noting that "focus groups are typically one method... used to create a complete picture of how a given issue affects a community of people.").

11. Id. (relaying that in a focus group, a conversation develops in which participants are likely to express a wide range of viewpoints). 
with the police response to domestic violence calls, refusals to arrest the abuser even when the survivor urged the officer to do so, and a lack of referrals to other sources of help such as women's shelters. ${ }^{12}$ Based on a comparison between the letter of Illinois law and the actual police response as detailed by these narratives, the gap between law and practice in rural Illinois becomes evident. In order to improve police response in rural Illinois, a normative solution is proposed. By requiring that all officers responding to a domestic violence call fill out a detailed risk assessment form and a checklist of their duties under the Illinois Domestic Violence Act, officers should be more apt to follow through with all of their legal duties and arrest the offender where appropriate.

This Article begins in Part II by situating Illinois domestic violence law in a national context by examining the history of mandatory arrest laws, as well as the discretionary nature of mandatory arrest as recognized by Supreme Court precedent. ${ }^{13}$ In Part III, the legal obligations of law enforcement officers under Illinois law are outlined to frame the narratives of the domestic violence survivors in a legal context. ${ }^{14}$ Then, through the use of survivor narratives in Part IV, the gap between law and practice regarding law enforcement response to domestic violence is expounded. ${ }^{15}$ Finally, Part V proposes a method of strengthening police responses to domestic violence calls in rural areas to respond to the issues presented in the survivor narratives. ${ }^{16}$

\section{FROM INACTION TO MANDATORY ACTION: THE HISTORY OF MANDATORY ARREST LAWS}

Quite frequently, the police are the first members of the larger legal community to interact with a woman experiencing domestic violence. ${ }^{17}$ Thus, it is crucial that police respond to rural domestic violence

12. See discussion infra Part III (detailing the narratives of the focus group participants and the experiences they had with Illinois police in relation to current state law).

13. See discussion infra Part II (giving the history of mandatory arrest laws in the U.S. beginning in 1970 and concluding with the Supreme Court's analysis of mandatory arrest laws).

14. See discussion infra Part III (discussing provisions of the Illinois Domestic Violence Act and the police response to the Act).

15. See discussion infra Part IV (utilizing the victims' accounts from the focus groups as examples of police not following the Illinois Domestic Violence Act).

16. See discussion infra Part V (noting that some steps have been taken to rectify the gap between the law and police practices, but that a type of form checklist would close the gap even further and greatly assist the victims of rural domestic violence).

17. See Eric G. Lambert et al., The Impact of Officer and Agency Characteristics on the Likelihood of Arrest in Domestic Violence Situations Among Rural Law Enforcement Officers, 22 J. POLICE CRIM. PSYCH. 100 (2007) (noting that "[p]olice are the gatekeepers to the criminal justice system in most domestic violence cases."). 
appropriately. The typical police response to domestic violence before 1970 was inaction. ${ }^{18}$ Police, like most of society, viewed domestic violence as a private matter and officers were loath to get involved in "family matters" or to arrest abusers. ${ }^{19}$ Many police agencies had policies requiring police not to arrest unless "there was severe injury to the victim or they personally witnessed the crime."20 However, police practices and policies dramatically changed in the 1980 s primarily due to two factors: police liability and the results of the Minneapolis Domestic Violence Experiment ("MDVE"). ${ }^{21}$

In the MDVE, Lawrence W. Sherman and Richard A. Berk conducted empirical research utilizing information gathered with the assistance of the Minneapolis Police Department to determine whether arresting domestic violence abusers decreases the likelihood of future acts of aggression. ${ }^{22}$ Sherman and Berk concluded that "[o]verall, the police data indicate that the separation treatment produces the highest recidivism, arrest produces the lowest, with the impact of [advising] (from doing nothing to mediation) indistinguishable from the other two effects." ${ }^{23}$ The results of the 1984 study were widely publicized and had a significant effect on public policy. ${ }^{24}$ Consequently, many states relied on the study when enacting mandatory arrest laws, despite the fact that the Sherman and Berk study advocated a presumption of arrest, not a mandate of the practice. ${ }^{25}$ Five

18. See Melissa Reuland et al., U.S. DeP'T of Just., Police-Community PARTNERSHIPS TO ADDRESS DOMESTIC VIOLENCE 3 (2006), http:// www.cops.usdoj.gov/files/RIC/Publications/domestic violence web3.pdf (relating that police policy dictated a passive, uninvolved response in all but the most blatant cases).

19. Id:; see Sally F. Goldfarb, Violence Against Women and the Persistence of Privacy, 61 OHIO ST. L.J. 1, 85 (2000); Elizabeth M. Schneider, The Violence of Privacy, 23 ConN. L. REV. 973, 983 (1991).

20. See REULAND ET AL., supra note 18, at 3 (citing E. BUZAWA \& C. BUzAWA, Domestic Violence: ThE ChANGING CRIMINAL Justice RESPONSE (Wesport ed., Auburn House) (1992)).

21. See id. (detailing the Minneapolis study and how it gave officers three options in responding to domestic violence: arrest, mediation, or separation). The study then found that arrest resulted in a lower recidivism rate. Id. See also Schneider, supra note 19 , at 982 (recognizing that lawsuits compel improved court practices and greater police response to arrest abusers).

22. See Lawrence W. Sherman \& Richard A. Berk, The Specific Deterrent Effects of Arrest for Domestic Assault, 49 AM. Soc. REv. 261, 261-63 (1984) (omitting lifethreatening or severe instances of assault from the design of the study for ethical reasons).

23. See id. at 267,270 (suggesting that the results of the study indicated that there should be a "presumption of arrest" in the police response to domestic violence, but not explicitly advocating mandatory arrest).

24. See G. Kristian Miccio, A House Divided: Mandatory Arrest, Domestic Violence, and the Conservatization of the Battered Women's Movement, 42 Hous. L. REV. 237, 281 (2005).

25. See Donna M. Welch, Comment, Mandatory Arrest of Domestic Abusers: Panacea or Perpetuation of the Problem of Abuse?, 43 DEPAUL L. REV. 1133, 1153 
attempts to replicate the study's suggestion that arrest significantly cuts recidivism yielded, at most, inconsistent results. ${ }^{26}$ A 2001 meta-analysis of the six studies conducted by the National Institute of Justice concluded that abusers were unlikely to commit another offense against the same survivor during the follow-up period regardless of the type of police intervention. ${ }^{27}$ The inconsistencies in the replication studies have prompted some scholars to call for the repeal of mandatory arrest laws because the purported justification for the laws-reducing recidivism-is unsupportable. ${ }^{28}$ On the other hand, some academics argue that "the police replication studies have such serious flaws that they cannot justify abandoning mandatory arrest." 29

Many states enacted mandatory arrest laws relying on the MDVE in the hope that arresting offenders in every instance of domestic abuse would deter future incidents of violence. ${ }^{30}$ However, states were equally motivated by a desire to avoid liability. ${ }^{31}$ A few widely publicized court cases holding police or police departments liable for a failure to protect domestic violence victims motivated some states to enact mandatory arrest laws. ${ }^{32}$ For instance, a domestic violence survivor, Tracy Thurman, was awarded \$2.9 million from a federal jury due to a police department's failure to protect her from her abusive husband. ${ }^{33}$ Despite her multiple

(1994) (citing studies documenting the connection between the MDVE and subsequently enacted mandatory arrest laws and reviewing these state statutes).

26. See Christopher D. MAXWEll Et AL., U.S. DeP'T OF JUST., The EFFEcts of ARREST ON INTIMATE PARTNER VIOLENCE: NeW EVIDENCE FROM THE SPOUSE ASSAUlT REPLICATION PROGRAM 1 (2001) (reporting that the MDVE was the first of six studies known as the National Institute of Justice's Spouse Assault Replication Program, which also included five subsequent replication experiments with inconsistent results that ultimately did not confirm or negate the implications of the MDVE).

27. See id. at 2 (summarizing the results of the study and finding that age and prior criminal record correlated to recidivism at a higher degree than type of intervention).

28. See, e.g., Cynthia Grant Bowman, The Arrest Experiments: A Feminist Critique, 83 J. CRIM. L. \& CRIMINOLOGY 201, 202 (1992) (noting that newer studies "conclude that arrest may in some cases lead to retaliation and thus bear an inverse relationship to specific deterrence."); see also Aya Gruber, The Feminist War on Crime, 92 IOWA L. REV. 741, 803-20 (2007).

29. See Joan Zorza, Mandatory Arrest for Domestic Violence: Why It May Prove the Best First Step in Curbing Repeat Abuse, 10 CRIM. JUST. 2, 51 (1995).

30. See Welch, supra note 25, at 1153-54.

31. See Marion Wanless, Note, Mandatory Arrest: A Step Toward Eradicating Domestic Violence, But Is It Enough?, 1996 U. ILL. L. REV. 533, 539 (1996) (noting that states view mandatory arrest laws as a way to motivate police officers to be proactive with regard to domestic disputes and also to limit the potential liability of police departments).

32. See, e.g., Sorichetti v. City of New York, 482 N.E.2d 70, 76 (N.Y. 1985) (holding that police incur liability when they have notice of a possible violation of a protection order and do nothing). See generally Sarah Mansolff Buel, Mandatory Arrest for Domestic Violence, 11 HARV. WOMEN's L.J. 213, 218 (1988).

33. See Thurman v. City of Torrington, 595 F. Supp. 1521, 1526-27 (D. Conn. 1984). 
requests for police protection, the police failed to act due to an "administrative classification" which permitted officers to afford less protection to women abused by a spouse or boyfriend as opposed to a stranger. ${ }^{34}$ Ultimately, Thurman's husband stabbed her in the chest, neck and throat multiple times. ${ }^{35}$ She was able to recover damages from the police officers and the police department by demonstrating that the above policy violated the Equal Protection Clause of the Fourteenth Amendment by discriminating on the basis of gender. ${ }^{36}$

Similarly, New York's highest state court held that a municipality could be liable under a negligence theory for failure to respond to a possible protective order violation when a special relationship existed between the police and the plaintiff. ${ }^{37}$ Additionally, the Seventh Circuit denied immunity to a deputy sheriff when the minor children of a woman murdered by her husband raised a negligence claim. ${ }^{38}$ Many states responded to the significant potential liability flowing from these cases by enacting mandatory arrest laws. ${ }^{39}$

However, despite the apparent mandate to arrest codified in such state laws, the Supreme Court has noted that these laws are, in essence, still discretionary. ${ }^{40}$ In Town of Castle Rock $v$. Gonzales in 2005, the Court addressed whether a state statute indicating that police officers "shall arrest" abusers who violate orders of protection conveys a due process right to survivors. ${ }^{41}$ The Court held that even though the language of the statute seemed to indicate intent on the part of the legislature to make arrests for violations of protective orders mandatory, police officers utilize a significant amount of discretion in making probable cause determinations. ${ }^{42}$ Thus, the survivor possesses no property right entitling her to police

34. Id.

35. Id. at 1525-26.

36. See id. at 1527-28 (holding that police officers cannot deny protection under the law because they feel that a husband has the prerogative to abuse his wife).

37. See Sorichetti, 482 N.E.2d at 75 (holding that there was a special relationship between Sorichetti and the City of New York which arose out of the order of protection and the police department's knowledge that Sorichetti's husband had a violent history).

38. See Losinski v. County of Tremealeau, 946 F.2d 544, 554 (7th Cir. 1991) (holding that once a deputy assumes his duty to protect, his obligation is no longer discretionary).

39. See Wanless, supra note 31 , at 538-39 (noting that states reduce not only potential liability through mandatory arrest laws, but also the problem of police inaction).

40. See Town of Castle Rock v. Gonzales, 545 U.S. 748, 760 (2005) (noting the "deep-rooted nature of law-enforcement discretion").

41. See id. at $752-56$.

42. See id. at 760-62 (explaining that there is a long history of police discretion being inherent in mandatory arrest statutes due to lack of resources or physical impracticality). 
enforcement under the Due Process Clause of the Constitution. ${ }^{43}$ The particular language at issue, included on the back of every restraining order and which mirrored the statutory domestic violence provision, said:

(b) A peace officer shall arrest, or, if an arrest would be impractical under the circumstances, seek a warrant for the arrest of a restrained person when the peace officer has information amounting to probable cause that:

(1) The restrained person has violated or attempted to violate any provision of a restraining order; and

(2) The restrained person has been properly served with a copy of the restraining order or the restrained person has received actual notice of the existence and substance of such order. ${ }^{44}$

The Court noted that "a true mandate of police action would require some stronger indication from the Colorado Legislature" ${ }^{" 45}$ because police must maintain discretion in enforcing the law due to practical necessity in circumstances such as these, where the defendant has fled the scene of the crime. ${ }^{46}$

After the Castle Rock decision was handed down by the Supreme Court, the Third Circuit Court of Appeals addressed a similar issue involving an even stricter mandate from the Pennsylvania legislature. ${ }^{47}$ In that instance, the police were instructed that they "shall arrest a defendant for violating an order." 48 The mandate did not contain the language regarding an impractical arrest like the statute at issue in Castle Rock. Additionally, the Pennsylvania statute permits survivors of abuse to initiate criminal proceedings on their own. ${ }^{49}$ However, neither statute permits survivors to "request, much less demand, an arrest." to limit the Castle Rock holding to facts involving a defendant who had fled the scene of the crime, the Third Circuit held that the survivor did not have a due process right to enforce her protective order. ${ }^{51}$ The court noted that, although Pennsylvania enacted statutory provisions which were much more

43. But see id. at 768 (recognizing that Colorado can still hold police accountable through liability under tort law).

44. Colo. Rev. Stat. § 18-6-803.5(3) (1999).

45. Castle Rock, 545 U.S. at 761.

46. See id. at 752-62 (explaining that when Jessica Gonzales first called the police to notify them that her children were missing from her front yard she was not able to tell them where her husband had taken the children).

47. Burella v. City of Pennsylvania, 501 F.3d 134, 142 (3d Cir. 2007).

48. Id. at 145 (quoting 23 PA. CONS. STAT. ANN. $\$ 6113($ a) (West 2003) (emphasis added)).

49. See id. at 146 (noting that a victim may file a criminal complaint but a district attorney can refrain from proceeding with the case).

50. Id. at 145; see Colo. REV. STAT. § 18-6-803.5(3) (1999).

51. Id. at 146. 
strongly worded than those of Colorado signaling Pennsylvania's intent to entitle victims of abuse to redress, the provisions could not overcome Castle Rock's substantial roadblocks. ${ }^{52}$

The roadblocks created by the Castle Rock decision are substantial indeed. It is hard to imagine any language that would overcome the presumption of discretion afforded to police officers when making arrests. Unfortunately, leaving domestic violence arrests to the sole discretion of police officers was the exact problem that prompted mandatory arrest legislation. The failure of police officers to take domestic abuse seriously and assist survivors by placing the abusive individual in jail warranted, indeed, necessitated, the mandatory arrest laws. ${ }^{53}$ Even when mandatory arrest laws are in place, police officers have a difficult time determining probable cause to arrest, which in turn triggers the mandatory arrest obligation. $^{54}$ One chief of police interviewed in a 2002 study noted that even though mandatory arrest was the official policy in Texas, his "goal [was] never to make an arrest." 55 Instead, his goal was to "find a solution to where [the couple] can handle their problems without going off at each other, preferably to move to counseling." ${ }^{, 56}$ Again, attitudes like thesewhere police officers would rather not take action to prevent domestic violence-spurred the mandatory arrest movement in the first instance. ${ }^{57}$

\section{LAW GOVERNING POLICE ACTION IN ILLINOIS}

In this Article, the narratives from the survivors in Section III will be directly contrasted with the provisions of the Illinois Domestic Violence Act and the Illinois Domestic Violence Protocol for Law Enforcement for purposes of analyzing rural police response to domestic abuse. The provisions of Illinois law governing police response to domestic abuse are outlined below.

\section{A. The Illinois Domestic Violence Act}

In Illinois, although a police officer is mandated to take action when he or she reasonably believes an individual has been abused by a family

52. Id. at 153 (Ambro, J., concurring).

53. See supra notes $17-20$ and accompanying text.

54. See Nikki R. Van Hightower \& Joe Gorton, A Case Study of Community-Based Responses to Rural Woman Battering, 8 VIOLENCE AGAINST WOMEN 845, 858 (2002) (attributing police difficulty in determining probable cause to inexperience and uncertainty).

55. See id. at 859 (explaining that many officers feel the decision to make an arrest is complicated by strained victim credibility).

56. Id.

57. See supra notes $17-20$ and accompanying text. 
member, the officer is not always required to arrest the abuser. ${ }^{58}$ The Illinois law is fairly strict, however, because it requires police officers to file a police report detailing the investigation and the result of the police response. $^{59}$ Additionally, some individual police departments in Illinois have instituted their own mandatory arrest policies. ${ }^{60}$

The Illinois Domestic Violence Act requires a police officer to take certain necessary actions when he "has reason to believe that a person has been abused, neglected, or exploited by a family or household member.",61 In the face of such a reasonable belief, the officer must "use all reasonable means to prevent further abuse, neglect, or exploitation ...."62 The officer has a number of enumerated options, including arresting the offender, accompanying the abused individual to her residence to retrieve her belongings, explaining to the abused individual how to obtain an emergency order of protection, providing the abused individual with a referral to a service agency, advising the abused individual how to preserve evidence, and providing any necessary transportation to a shelter, hospital, or court. ${ }^{63}$ An officer need not view physical evidence of bodily harm in order to arrest the offender. ${ }^{64}$ Further, a survivor's testimony alone can sustain a conviction for domestic battery. ${ }^{65}$

An officer is not required under the Act to arrest the abusive individual. ${ }^{66}$ However, each law enforcement agency is required to create and maintain "written policies regarding arrest procedures for domestic violence incidents ...."67 At least one city's published policy requires mandatory arrest in certain instances, including offenses where the officer has probable cause to believe a misdemeanor has been committed and the

58. See 750 Ill. Comp. Stat. 60/304 (2009) (listing options other than arrest, such as staying with the victim while she collects her belongings and leaves, referring the victim to a service agency, or providing transportation to a medical facility or safe shelter).

59. See id. (requiring that a report only be made when the police response does not result in an arrest or criminal proceeding).

60. See id. at 60/301.1 (2009) (mandating each police department to develop and implement rules and procedures for domestic violence cases).

61. Id. at 60/304 (2009).

62. Id.

63. Id.

64. See Simmons v. Pryor, 26 F.3d 650, 654 (7th Cir. 1993) (citing People v. Foster, 431 N.E.2d 430, 435 (Ill. App. Ct. 1982)).

65. Id. (citing People v. Wilkinson, 551 N.E.2d 327, 329 (Ill. App. Ct. 1990)).

66. See Farrar v. City of Chicago, 291 F. Supp. 2d 747, 755 (N.D. Ill. 2003) (holding defendant police officers did not breach their statutory duty by failing to arrest a suspected abuser because they wrote a police report and told the victim how to initiate criminal proceedings).

67. 750 ILL. COMP. STAT. 60/301.1 (2009). 
victim has visible signs of injury. ${ }^{68}$ If the officer chooses not to arrest the offending party, the officer must:

(1) Make a police report of the investigation ... and the disposition of the investigation ...; (2) Inform the victim of ... [her] right to request that a criminal proceeding be initiated where appropriate, including specific times and places for meeting with the State's Attorney's office... ; [and] (3) Advise the victim of the importance of seeking medical attention and preserving evidence ... ${ }^{69}$

Domestic battery, a crime under Illinois law, occurs when an abuser "intentionally or knowingly... [c]auses bodily harm to any family or household member... [or] [m]akes physical contact of an insulting or provoking nature with any family or household member. .." If If the abuser is arrested, the State's Attorney may file a petition for an order of protection, which may be granted as a condition of the abuser's pre-trial release. ${ }^{71}$ Additionally, if the abuser violates the order of protection by ignoring the stay away order, engaging in further abuse or other serious violations, the abuser may be arrested and prosecuted for the violation. ${ }^{72}$

\section{B. The Illinois Domestic Violence Protocol for Law Enforcement}

To better assist domestic violence survivors in Illinois, the Domestic Violence Training and Curriculum Task Force, in collaboration with the Illinois Criminal Justice and Information Authority, updated the Illinois Domestic Violence Protocol for Law Enforcement, Prosecution, and the Judiciary in 2007 ("Protocol"). ${ }^{73}$ The Protocol is aimed at providing local

68. See Riverside Police, General Order 96-011: Domestic Violence (Nov. 12, 1996), http://www.google.com (search "Riverside General Order 96-011," follow hyperlinked first result, and view as HTML) (requiring Riverside police to arrest offenders in every instance where: (1) the officer has probable cause to believe that the offender has committed a felony, provided that the officer has contacted the State's Attorney's office and has followed standard procedures for approval of felony arrests; (2) the officer has probable cause to believe that the offender has committed a misdemeanor and that the victim has visible injuries or that a weapon was used; (3) the officer has probable cause to believe that a misdemeanor was committed by an offender who has previously committed acts of domestic violence; (4) the offender has committed an offense in the presence of the officer; or (5) the offender has violated a valid order of protection).

69. 750 ILl. COMP. STAT. 60/304(b)(1)-(3) (2009).

70. 720 Ill. COMP. STAT. 5/12-3.2 (2009).

71. 750 ILL. COMP. STAT. 60/202(a)(3) (2009) (stating that an order of protection may be granted as a condition of release if the defendant is charged with an offense against a member of the defendant's family or household, and if the alleged victim is named as a petitioner on the order of protection).

72. 750 Ill. Comp. Stat. 60/223 (2009).

73. See Domestic Violence Training and Curriculum Task Force, Illinois Criminal Justice Information Authority, MODEL DOMESTIC VIOLENCE PROTOCOL FOR LAW ENFORCEMENT, PROSECUTION, AND THE JUDICIARY ch. 1, 2-3 (2007) [hereinafter Domestic Violence Training and Curriculum Task Force], http:// www.icjia.state.il.us/public/pdf/IDVMP/Model\%20DV\%20Protocol\%202007.pdf 
officials with "best practices" in the area of domestic violence methods and procedures. $^{74}$ In addition to explaining the officer's duties under Illinois law as outlined above, the Protocol provides specific guidance regarding how police officers should respond to the crime scene if the abuser has fled the immediate area. ${ }^{75}$ If the abuser has left the scene of the crime, the officer should take the following steps to ensure the safety of the abused individual: search the immediate area for the abuser, determine whether there is a high risk that the abuser will return and document such risks, issue a broadcast to other officers in the area, and take any necessary steps to protect the abused individual and her children including transporting them to a safe location. ${ }^{76}$ Additionally, the Protocol reminds officers that "some victims may appear out of control and unreasonable" when the police arrive on the scene. ${ }^{77}$ Similarly, an abused individual may deny that the abuse occurred or refuse to admit that she is in an abusive relationship. ${ }^{78}$ The Protocol instructs officers to "suspend [their] judgment" regarding the abused individual and thoroughly investigate the scene of the crime, even if the abused individual is unhelpful or difficult. ${ }^{79}$

Importantly, the Protocol includes a section designed to advise law enforcement officers of the special needs associated with rural survivors of domestic violence. ${ }^{80}$ Officers are encouraged to "be creative" to assist survivors by providing referrals to the nearest domestic violence service providers, even if those services are not located within county lines. ${ }^{81}$ Additionally, police officers are encouraged to drive survivors to the county line, where necessary, and seek assistance from neighboring county police in order to transport survivors to domestic violence shelters. ${ }^{82}$ Officers are cautioned to "seek peer and supervisor support to ensure that

(delineating goals including deterrence, victim safety, and police and judicial sensitivity).

74. See id. at ch. 1, 1 (conceding that it is not possible to create state-wide policies to address domestic violence because each community has different needs).

75. See $i d$. at ch. 2, 13-14 (contending that a police officer should find out what kind of car the abuser is driving, obtain a photograph, and search locales where the abuser may have gone).

76. Id.

77. See id. at ch. 2, 3 (noting that the unreasonable behavior may appear "confusing or contradictory" and stressing that "officers must have a thorough understanding of the dynamics of domestic violence to accurately interpret what has taken place at the scene and proceed with the investigation.").

78. See id. at ch. 2, 11 (explaining the importance of interviewing the victim separately from the alleged abuser to ensure reliability).

79. See id. at ch. 2, 4 (suggesting officers should focus on the crime and the abuser's behavior rather than on a victim's seemingly complicit attitude).

80. Id. at ch. $2,40-41$.

81. Id. at ch. 2,41 .

82. Id. 
they are responding objectively" if they are faced with an abusive situation "involving a family known to the law enforcement officer." 83 These provisions recognize the increased risks that rural domestic violence survivors face and attempt to convey this important information to the police.

\section{RURAL DOMESTIC VIOLENCE SURVIVORS' NARRATIVES}

\section{"I still call the police every time even though they say to me 'you should probably get some counseling.}

Many of the focus group participants expressed frustration regarding the lack of assistance they received from police officers in the area. ${ }^{85}$ One survivor's story is particularly telling in this respect. She points out that "in the beginning ... it was a situation where, oh-you really don't want to take him to jail, right? ... It's a small community and everybody is buddybuddy, and it's a good ol' boys club. ${ }^{, 86}$ This narrative demonstrates a key difference between rural and urban crime scenes. In an urban setting, the officer arriving at the scene is less likely to be personally acquainted with the offender; however, in a small, rural community this likelihood increases. ${ }^{87}$ Her story also suggests a lack of respect for the autonomy of the individual's choice regarding whether to formally press charges.

Some scholars argue that mandatory arrest laws eliminate survivors' autonomy by eliminating their choice as to whether they wish to have their abuser taken into custody. ${ }^{88}$ Such debates regarding the efficacy and/or

83. Id.

84. Interview with Focus Group 1, supra note 3, at 4.

85. See id; see also Interview with Focus Group 3, supra note 2; Interview with Focus Group 2, Domestic Violence Survivors (Aug. 24, 2007) (on file with the American University Journal of Gender, Social Policy \& the Law) (documenting that five of the nine participants voiced their frustration with police responses in their community).

86. Interview with Focus Group 1, supra note 3, at 2.

87. See Neil Websdale, Rural Woman Battering and the Justice System: AN ETHNOGRAPHY 102-06 (1998) (citing numerous examples of rural battered women who declined to call the police because the local officer was a brother, cousin, or friend of her abuser); see also Grama, supra note 4, at 177.

88. Some members of the legal academic community have expressed serious concerns surrounding the lack of autonomy afforded to domestic violence survivors under mandatory arrest and no-drop prosecutorial mandates. Compare Miccio, supra note 24 , at 293-94, 322 (calling for open challenges to the "protagonist" view "that the societal benefits of mandatory state intervention outweigh the short-term costs of women's autonomy"), with Dennis P. Saccuzzo, How Should the Police Respond to Domestic Violence: A Therapeutic Jurisprudence Analysis of Mandatory Arrest, 39 SANTA ClARA L. REV. 765, 779-80 (1999) (disputing the argument that mandatory arrest disempowers women because it protects women who do not fully understand the risks they face from their abusers, who, for cultural reasons, will not betray their abusers by requesting arrest). Similarly, research indicates that mandatory arrest and 
utility of mandatory arrest policies are inapposite in this instance. The Illinois Domestic Violence Act does not require an officer to arrest the abuser in a domestic violence situation, but instead instructs each law enforcement agency to make its own arrest policy. ${ }^{89}$ Even if local authorities have adopted mandatory arrest policies due to receipt of Violence Against Women Act ("VAWA") funds ${ }^{90}$ or internal protocol," the narrative in this instance indicates that the abused individual wanted the police to make the arrest. Here, the officers attempted to persuade the survivor not to press charges. The refusal of law enforcement officers to exercise appropriate arrest powers provides an illustration of the paradigm that prompted state legislatures to enact mandatory arrest laws in the 1990s. ${ }^{92}$

Additionally, the survivor in this instance recognized her own vulnerability by repeatedly seeking assistance not only from the police, but also from the local crisis center. She explained that "in the beginning it was very difficult, even to get a referral .... [I]t took two or three times of calling the authorities before they referred me [to a women's crisis center]." 93 The officer also violated his obligations under Illinois law by failing to refer this survivor to the local domestic violence agency. ${ }^{94}$

This survivor's narrative also demonstrates that the police may be unwilling to take the necessary action to enforce the law until the situation becomes excessive. "I called [the police] out to my home about a dozen times. They finally said, 'You know, you can get an emergency order of protection.' Really?"'95 The repeated action of calling the police out to her home, where the police took no action in the form of an arrest or issuance of an emergency order of protection, would be enough to discourage a similarly situated survivor from continuing to call the police for assistance

no-drop prosecution policies and procedures may not reduce crime or recidivism among abusers. See Bowman, supra note 28, at 202. Despite these concerns, the Violence Against Women Act ("VAWA") continues to provide grants aimed at encouraging states, local courts, and governmental units to treat domestic violence as a serious crime by requiring all grantees to "certify that their laws or official policies ... encourage or mandate arrests of domestic violence offenders based on probable cause that an offense has been committed ..." 42 U.S.C. $3796 \mathrm{hh}(\mathrm{c})(1)(\mathrm{a})(2000)$.

89. 725 ILl. COMP. Stat. 5/112A-27 (2009).

90. See Deborah Epstein, Procedural Justice: Tempering the State's Response to Domestic Violence, 43 WM. \& MARY L. REV. 1843, 1856 (2002) (noting that VAWA made federal grant funds conditioned upon mandatory arrest policies).

91. See Riverside Police General Order, supra note 68, at 4.

92. See Epstein, supra note 90, at 1851-55.

93. Interview with Focus Group 1, supra note 3, at 2.

94. See 750 ILL. COMP. STAT. 60/304(a)(5) (2009) (requiring that police officers provide domestic abuse victims with at least one referral to an accessible service agency).

95. Interview with Focus Group 1, supra note 3, at 3. 
when confronted with abuse. Additionally, the police failed to provide this survivor with information about her rights under Illinois law, such as her ability to file for an emergency order of protection, which is effective anywhere from fourteen to twenty-one days. ${ }^{96}$ Such apathy on the part of law enforcement officers could place the survivor and her children in an extremely dangerous situation.

Another focus group participant explained that by the time the police reached her home, the abuser had fled. When she told the officer that he just left, the officer responded, "Well, he's gone now. What do you want me to do? ... There is nothing I can do." didn't let me explain... what had happened...."98 In an even more severe instance, a woman's husband threatened to "pull a gun ... and shoot" her. ${ }^{99}$ Her husband fled when she called the police, taking the gun with him. "I h[ad] no idea where he went, but because he was gone, there was nothing that the police could do. I said, 'well, what the hell do I do when he comes back?"'100 As noted above, the Protocol provides that if the abuser has fled the scene of the crime, the police should attempt to locate the abuser, notify other police officers in the area, and take steps to protect the safety of the abused individual and her children. ${ }^{101}$ In the first instance described above, the officer provided the survivor with a pamphlet after she requested additional information regarding protection orders. However, in both instances, the officer left the scene without attempting to locate the abuser, escorting the woman to safety, or ascertaining any immediate safety risk.

Additionally, one participant's narrative demonstrates that not all law enforcement officers are clear on the letter of the law. She noted that she was being stalked and threatened by her husband after they had physically separated, but before the divorce. ${ }^{102}$ She was told by law enforcement that none of the stalking laws applied because they were still married. ${ }^{103}$ However, the Illinois domestic violence law applies to such harassment behavior and the law broadly applies to both current and past household and dating relationships, including non-married couples. ${ }^{104}$

96. See 750 Ill. Comp. Stat. 60/217 (2009).

97. Interview with Focus Group 3, supra note 2, at 8.

98. Id.

99. Id. at 34 .

100. Id.

101. See Domestic Violence Training and Curriculum Task Force, supra note 73, at ch. 2, 13-14.

102. See Interview with Focus Group 2, supra note 85, at 25.

103. See id.

104. See 750 ILL. COMP. STAT. 60/103(6), (7) (2009) (defining harassment as including any conduct that is unnecessary to accomplish a reasonable purpose, would 
A 2005 study examining domestic violence service agency intake data for the State of Illinois between 1990 and 1995 indicated that rural survivors were less likely to contact police for assistance than urban survivors. ${ }^{105}$ In fact, the study found that survivors in "rural settings, although they do use the police as a referral source, are less likely to do so when compared to women in Cook County..." 106 The researchers posited that this might occur due to the women's concern "that the police know and support their abusers as some works suggest."107 The focus group narratives demonstrate that there may be two concerns at work. First, the community is small and the police officers may have a friendly relationship with the abuser or the abuser may be a well-known individual in the community; and second, the police response may be inadequate and discourage abused individuals from calling the police. The narratives of the focus group participants are consistent with the findings from the 2005 study and indicate that further research in the area of police response to domestic violence in rural Illinois should be conducted to determine the pervasiveness of this problem.

\section{IMPROVING RURAL LAW ENFORCEMENT RESPONSE TO DOMESTIC VIOLENCE CALLS}

Although Illinois law already requires police to take steps to eradicate domestic violence, otherwise referred to as a "mandatory action" law, the law does not mandate arrest. ${ }^{108}$ However, some police departments have already implemented a mandatory arrest policy. If the Illinois legislature enacted a mandatory arrest statute, would the problems of police enforcement be solved, especially in rural Illinois?

It seems that the problem requires more than a mandatory arrest law or policy. In the Castle Rock decision, the Supreme Court expressly stated that mandatory arrest laws still permit the police to use discretion in making probable cause determinations and exercising the power to arrest. ${ }^{109}$ Likewise, under laws even more strict than the one at issue in

cause emotional distress to a reasonable person, and does cause emotional distress to the victim).

105. See Susan F. Grossman et al., Rural Versus Urban Victims of Violence: The Interplay of Race and Religion, $20 \mathrm{~J}$. FAM. VIOLENCE 71, 80 (2005) (suggesting that anti-domestic violence community education is more important in rural communities because rural women rely more on family and friends for advice).

106. Id.

107. Id. at 78.

108. See 750 ILL. COMP. STAT. 60/301.1 (2009) (directing law enforcement agencies to develop arrest procedures for domestic violence incidents, but not requiring that the policy be automatic arrest).

109. See Town of Castle Rock v. Gonzales, 545 U.S. 748, 760 (2005) (observing that "[a] well established tradition of police discretion has long coexisted with 
Castle Rock, appellate courts have continued to acknowledge that police discretion is broad despite a legislature's attempt to create a truly "mandatory" arrest law. ${ }^{10}$

Additionally, the Illinois Legislature has already taken action to fill in the gaps of police liability created by Castle Rock. Although a domestic violence survivor has no cause of action under due process for a police officer's failure to arrest or take actions to protect her, she may sue a police officer, along with his supervisor or employer, for "willful or wanton misconduct." 111 Furthermore, issues related to the failure to arrest have survived a motion to dismiss where police knew that a particular plaintiff had a protective order against her former boyfriend but did not provide "supporting materials to show what evidence from [the] investigation ruled out probable cause." 112 It is possible that by flooding the courthouse with failure to arrest claims in Illinois, domestic violence survivors could initiate positive policy change. ${ }^{113}$

While it is true that a string of successful civil claims against police departments for failing to enforce domestic violence laws in rural Illinois would probably encourage police departments to "toughen up" on domestic abuse, it is undesirable to wait for these instances to occur before changing procedures, policies, and responses. The focus group participants eagerly agreed that these types of changes need to occur at a grassroots level. Increased education for police officers and departments ${ }^{114}$ and community awareness campaigns ${ }^{115}$ were both mentioned by the participants as possible solutions.

It is also likely that more detailed police procedures might encourage police officers to take action when responding to a domestic violence call. Specifically, some research has examined the results when probation officers were provided with forms to fill out when responding to a domestic

apparently mandatory arrest statutes.").

110. See Burella v. City of Philadelphia, 501 F.3d 134, 145 (3d Cir. 2007) (noting that a Pennsylvania law, which said an officer "shall arrest" a defendant still allows for officer discretion, particularly because the law is silent as to whether a victim can demand, or even request, an arrest).

111. 750 Ill. COMP. STAT. 60/305 (1986).

112. See Lacey v. Vill. of Palestine, 882 N.E.2d 1187, 1198 (Ill. App. Ct. 2008) $r e v ' d, 2009$ WL 426520 (Ill. Feb. 20, 2009) (finding a genuine issue of material fact existed as to whether the defendant-officers had probable cause to arrest because the officers knew about the history of domestic violence and that the victim had a protective order).

113. See Wanless, supra note 31 , at $538-39$ (noting that the mandatory arrest provisions were, in part, developed in response to litigation relating to errant police domestic violence procedures).

114. See Interview with Focus Group 1, supra note 3, at 18.

115. Id. at 20. 
violence dispatch in Colorado. ${ }^{116}$ Colorado, unlike Illinois, has a mandatory arrest law in place. ${ }^{117}$ Thus, the forms were "designed to be a short statistical tool based on a quick criminal history review that could be made available to prosecutors, judges, and probation officers soon after an offender [was] arrested."118 The forms were created using data compiled from prior police reports and arrests to predict the "risk for reoffending, noncompliance with court [sic] and probation orders, and, thus, the higher risk to" survivors. ${ }^{119}$ The form requires probation officers to enter data in twelve categories, such as criminal history (including non-domestic violence offenses), prior domestic violence arrests, history of drug or alcohol abuse, weapons used in commission of a crime, employment, and recent separation from the domestic violence survivor. ${ }^{120}$ Such data could be readily available to police officers responding to a domestic violence call. ${ }^{121}$

Researchers compiled data from 1,465 men in four judicial districts. ${ }^{122}$ Using follow up interviews with survivors and investigation of criminal records after eighteen months, researchers were able to determine that the form checklist was a fairly accurate predictor of recidivism. ${ }^{123}$ Thus, police officers were successfully using the form to implement responses in proportion to the dangerousness of the abuser.

The use of such forms in Illinois could strengthen police response in both rural and urban areas. However, it is probably even more necessary in more remote locations, where police response may be less adequate. In addition to using similar violence predictor forms, rural Illinois officers could also benefit from a form that includes their duties under the Illinois Domestic Violence Act. ${ }^{124}$ Thus, a form containing a method to determine

116. See Kirk R. Williams \& Amy Barry Houghton, Assessing the Risk of Domestic Violence Reoffending: A Validation Study, 28 L. \& HUM. BEHAV. 437, 440 (2004) (explaining that probation officers evaluated domestic violence offenders based on a set of response categories; categories related to prior restraining orders were given more weight).

117. See id. at 440 (citing Colo. Rev. StAT. § 18-6-803.6(1) (2004)).

118. Id.

119. Id. at 441 .

120. See id. at 452 (calculating the defendant's risk of re-offending score based on the number of times the defendant previously violated enumerated risk factors).

121. See Mandeep Talwar, Note, Improving the Enforcement of Restraining Orders After Castle Rock v. Gonzales, 45 FAM. CT. REV. 322, 329 (2007) (citing N. Zoe Hilton et al., A Brief Actuarial Assessment for the Prediction of Wife Assault Recidivism: The Ontario Domestic Assault Risk Assessment, 16 PSYCHOL. ASSESSMENT 267, 268 (2004)) (indicating that after minimal training police officers were easily able to assess and understand offender statistical risk information).

122. See Williams \& Houghton, supra note 116 , at 442 .

123. See id. at 449-50.

124. The author would like to thank Ann Bartow, professor of law at the University of South Carolina School of Law and author of the Feminist Law Professors Blog, for 
whether to arrest an abuser could also contain a checklist reminding officers to secure the survivor, offer her domestic violence literature, inform her regarding protective order rights, and more. In this manner, basic police officer duties will most certainly be met on the front lines and police officers will make more informed judgments regarding arrest decisions.

\section{CONCLUSION}

Mandatory arrest is not a "panacea" 125 and Illinois law already contains a thorough list of police officer duties when responding to domestic violence calls. However, too frequently police officers are not responding adequately to domestic violence situations, especially in rural parts of Illinois. By implementing further controls, such as increased police training and easy-to-use forms, first responders will be better informed as to their duties under the Domestic Violence Act. It is unreasonable to wait for further tragedies to motivate police departments to better prepare their officers. Instead, police departments in Illinois, like those in Colorado, should take the initiative and provide their officers with detailed forms in order to take the guess work out of domestic violence response. We owe it to all of the domestic violence survivors involved in this study-and to others who have not yet had the opportunity to share their narratives.

suggesting that a more detailed checklist would be the preferable option for firstresponders.

125. See Welch, supra note 25, at 1156-64 (arguing that instead of mandatory arrest laws, communities should provide battered women with better resources, such as more emergency shelters, counseling programs, and economic support). 
